\title{
Accumulation of heavy metals and antioxidant responses in Vicia faba plants grown on monometallic contaminated soil
}

\author{
Aleksandra Nadgórska-Socha • Alina Kafel • \\ Marta Kandziora-Ciupa • Janina Gospodarek • \\ Agnieszka Zawisza-Raszka
}

Received: 22 March 2012 / Accepted: 10 September 2012 /Published online: 23 September 2012

(C) The Author(s) 2012. This article is published with open access at Springerlink.com

\begin{abstract}
The purpose of this study was to explore the effects of soil contamination by selected metals (cadmium, copper, nickel, lead or zinc) on the antioxidant response of Vicia faba plants. The levels of the antioxidants: glutathione, proline, non-protein thiols, as well as guaiacol peroxidase and catalase activities were measured in the upperparts of plants. Additionally, the potential bioavailability of metals in the soil and their concentrations in $V$. faba plants were compared. Treatment with metal caused the problem of an elevation in its bioavailability in soil and its concentration in leaves and stems. The most serious problems seemed to be metal elevations in soil, especially $\mathrm{Zn}$ and $\mathrm{Ni}$ as well as in the aerial parts of $V$. faba plants. The antioxidant responses appeared to be metal specific. The elevation of guaiacol peroxidase activity in leaves and stems as well as the proline in leaves was the only more general reaction to metal exposure. Upon analysis of the effects of soil metal contamination on $V$. faba plants, we recommend the use of some measurements such as guaiacol peroxidase activity and proline level as useful tools in biological monitoring.
\end{abstract}

Responsible editor: Elena Maestri

A. Nadgórska-Socha $(\bowtie) \cdot$ M. Kandziora-Ciupa

Department of Ecology, University of Silesia,

Bankowa 9,

40-007 Katowice, Poland

e-mail: aleksandra.nadgorska-socha@us.edu.pl

A. Kafel · A. Zawisza-Raszka

Department of Animal Physiology and Ecotoxicology,

University of Silesia,

Bankowa 9,

40-007 Katowice, Poland

J. Gospodarek

Department of Agricultural Environment Protection,

University of Agriculture in Krakow,

Mickiewicza 21,

31-120 Kraków, Poland
Keywords Antioxidant response - Metal contamination · Viciafaba
Abbreviations
CAT Catalase
GSHt Glutathione total
POD Guaiacol peroxidise

\section{Introduction}

There are multiple sources of soil contamination with heavy metals such as industrial wastes, agriculture fertilizers and roadways. The problem of soil contamination may be of great importance for crops grown in the vicinity of heavy industrial sites. In such surroundings, the uptake of metals depends on the bioavailability of metals (Teklić et al. 2008). The bioavailable fraction of heavy metals is an issue of particular concern from ecological, toxicological and health standpoints, due to the possible penetration into most environmental segments, including food chains (Kucharski et al. 2005).

Heavy metals like cadmium $(\mathrm{Cd})$, copper $(\mathrm{Cu})$, nickel $(\mathrm{Ni})$, lead $(\mathrm{Pb})$, zinc $(\mathrm{Zn})$ may affect the status of plants differently. Some of them are essential elements for cellular metabolism $(\mathrm{Cu}, \mathrm{Zn}, \mathrm{Ni})$, while some are non-essential $(\mathrm{Cd}$, $\mathrm{Pb}$ ). $\mathrm{Cu}$ and $\mathrm{Zn}$, are constituents of many enzymes and other proteins. The requirement of plants for $\mathrm{Ni}$ appears to be mainly related to its role in forming the active metallocentre of urease (Gratão et al. 2005; Page and Feller 2005).

The redistribution of metals within plants is metal specific (Page and Feller 2005). The elevation of non-essential metals like $\mathrm{Pb}, \mathrm{Cd}$ and micronutrients such as $\mathrm{Zn}, \mathrm{Cu}$ and $\mathrm{Ni}$ may be the cause of several negative aspects of oxidative stress (Zengin and Munzuroglu 2005; Meng et al. 2007). Therefore, the effectiveness of a plant's antioxidant defense may be crucial for elucidating its tolerance mechanisms to heavy metals, which 
are common contaminants of soil. The synthesis of diverse metabolites in millimolar concentrations, particularly specific amino acids (such as proline and histidine) and peptides such as glutathione (GSH) or phytochelatins (PC), may be important for defense mechanisms against a metal's action. Low molecular weight antioxidants such as proline, ascorbic acid or glutathione detoxify oxygen free radicals. Non-protein compounds, rich in - $\mathrm{SH}$ groups, are capable of binding metal ions and forming non-toxic complexes with metals. They are also involved in determining a plant's tolerance to heavy metal ions, which is another important factor (Wei et al. 2003; Sharma and Dietz 2006; Sun et al. 2007; Xu et al. 2009). The accumulation of proline, a very effective singlet-oxygen quencher and redox active metal ions binder, activates and protects enzymes such as catalase (CAT) and guaiacol peroxidase (POD) (Teklić et al. 2008). The latter enzyme is involved in several processes such as cell growth, auxin catabolism, lignifications as well as abiotic and biotic stress responses (Fang and Kao 2000; Cui and Wang 2006).

Information about the response of particular cultivations to heavy metal contamination would be important in an assessment of the safe production of crops. On the other hand, some plant cultivation on metal-contaminated soil could be connected with the immobilization of metals by plants. In the experiment of Lopareva-Pohu et al. (2011), the bioavailability of metals as well as their uptake by two plants, Lolium perenne (Poaceae) and Trifolium repens (Fabaceae), was investigated. The examined plants were able to reduce the bioavailability of the elements. Probst et al. (2009) emphasized the important role of other leguminous representatives for instance Vicia faba plants, in cultivation on soil and metal tailings. They found that translocation was most significant for $\mathrm{Zn}$ and $\mathrm{Cd}$ but limited for $\mathrm{Pb}$.

This study was undertaken in order to quantify the impact of different heavy metals applied to the soil on the antioxidant status of $V$. faba plants and to evaluate plant growth. The usefulness of these measurements as biomarkers of metal soil contamination was evaluated. To achieve this goal, we determined and compared the levels of metals in the leaves and stems of $V$. faba plants. We studied bioavailability of single metals, $\mathrm{Cd}, \mathrm{Cu}, \mathrm{Ni}, \mathrm{Pb}$ and $\mathrm{Zn}$, in the soils at the end of the experiment. We also determined the levels of antioxidants (non-protein thiols, GSHt, and proline) and antioxidant enzymes (guaiacol peroxidase and catalase) in order to complement chemical measurements.

\section{Materials and methods}

\section{Soil}

The field study area was in Zagaje Stradowskie (a rural village situated in the province of Świętokrzyskie, Poland), whose characteristics were given in Kafel et al. (2010). Broad bean plants ( $V$. faba ssp. major) were cultivated in pots filled with soil contaminated with heavy metals. The soil $\mathrm{pH}$ was 5.3 in $1 \mathrm{M} \mathrm{KCl}, 6.1$ in water and the soil contained $1.13 \%$ of organic carbon. The soil was amended with heavy metals 1 month before cultivation and allowed to equilibrate. Each pot contained $9.8 \mathrm{~kg}$ of separately prepared soil. A thin layer of crumbled soil was put on plastic foil, sprayed with an appropriate mixture of fertilizer and metal and then soil was thoroughly mixed. This procedure was repeated several times. The following basic soil fertilization was applied- $0.7 \mathrm{gN}$ (as $\mathrm{NH}_{4} \mathrm{NO}_{3}$ ), $0.8 \mathrm{~g} \mathrm{P}_{2} \mathrm{O}_{5}$ (as $\mathrm{KH}_{2} \mathrm{PO}_{4}$ ) and $1.2 \mathrm{~K}_{2} \mathrm{O}$ (as $\mathrm{KCl}$ ) per one pot with a natural content of heavy metals (control group) and with soil contaminated with $\mathrm{Pb}, \mathrm{Cd}, \mathrm{Cu}, \mathrm{Ni}$ and $\mathrm{Zn}$. The heavy metals were added to the soil as a solution of $\mathrm{Pb}\left(\mathrm{NO}_{3}\right)_{2}$, $\mathrm{CdSO}_{4}$ × $8 \mathrm{H}_{2} \mathrm{O}, \mathrm{CuSO}_{4}, \mathrm{NiSO}_{4}$ × $7 \mathrm{H}_{2} \mathrm{O}, \mathrm{ZnSO}_{4}$ × $7 \mathrm{H}_{2} \mathrm{O}$. The basis for the choice of metal concentrations in soil was the IUNG trace metals contamination level classification (III level-mean contamination). Limit values of heavy metal content in the topsoil were $5 \mathrm{mg} \mathrm{kg}^{-1} \mathrm{Cd}, 100 \mathrm{mg} \mathrm{kg}^{-1} \mathrm{Cu}$, $1,000 \mathrm{mgkg}^{-1} \mathrm{~Pb}, 1,500 \mathrm{mgkg}^{-1} \mathrm{Zn}, 150 \mathrm{mgkg}^{-1} \mathrm{Ni}$. The heavy metal concentrations and the applied heavy metal doses in this study are presented in Table 1.

\section{Plant material}

$V$. faba plants were cultivated for 2 months. Five plants were grown in each from ten pots. Summarized, each experimental group included 50 plants. Shoots 10,30 and $80 \mathrm{~cm}$ in length (depending on metal treatment), and covered with leaves were collected randomly from the $V$. faba plants. The youngest, fully expanded, mature leaves and stems were used for the analyses. From each pot per treatment the plant material were mixed and each biochemical experiment was performed in five replicates. After a 2-month cultivation, the length between the apical leaf and basal stem was also measured and the shoot length and biomass of the whole aerial parts of plant were estimated. Each experimental group included twenty plants (from each pot two plants have been measured and weighted).

Analysis of metal concentration in the soil and plants samples

The concentrations of the metals $\mathrm{Pb}, \mathrm{Cd}, \mathrm{Cu}, \mathrm{Ni}$, and $\mathrm{Zn}$ that were used for soil treatment, were analyzed in particular soil fractions and in the leaves and stems of plants. The soil metal content was estimated according to the method of Bouwman et al. (2001) and Ostrowska et al. (1991). Airdried soil samples were sieved through a sieve with 1-mm pores and used for metal extraction with $0.01 \mathrm{M} \mathrm{CaCl}_{2}$ (potentially bioavailable elements) or with $2 \mathrm{M} \mathrm{HNO}_{3}$ (acid 
Table 1 Experimental groups according to heavy metal concentrations ( $\mathrm{mg} \mathrm{kg}^{-1}$ soil d.w.)

\begin{tabular}{llllll}
\hline Experimental groups (heavy metals content) & $\mathrm{Pb}$ & $\mathrm{Cd}$ & $\mathrm{Cu}$ & $\mathrm{Ni}$ & $\mathrm{Zn}$ \\
\hline Initial soil-control & 28.2 & 0.6 & 8.2 & 12.8 & 52.9 \\
Applied heavy metal doses & 530 & 4 & 85 & 110 & 1,000 \\
\hline
\end{tabular}

extracted elements). During $\mathrm{CaCl}_{2}$ extraction, $5 \mathrm{~g}$ of soil with $50 \mathrm{~mL}$ of a $0.01 \mathrm{M} \mathrm{CaCl}_{2}$ solution was shaken for $5 \mathrm{~h}$. The $\mathrm{HNO}_{3}$-extractable fraction was obtained by shaking a sample (10 g) with $100 \mathrm{~mL}$ of $2 \mathrm{M} \mathrm{HNO}_{3}$ for $1 \mathrm{~h}$. Finally, the content of metals was measured in the filtered extracts using flame absorption spectrometry (Unicam 939 Solar). The experiments were performed in five replicates.

In order to determine the heavy metal concentrations in the upper part of plants (leaves and stems), plant material was cleaned of any patches of deposited aphid honeydew and other surface contaminants, washed in tap, next in distilled water. It was then dried at $105{ }^{\circ} \mathrm{C}$. A portion of $0.25 \mathrm{~g}$ dried plant material was digested with $5 \mathrm{~mL}$ of $\mathrm{HNO}_{3}$ at $110^{\circ} \mathrm{C}$ and then diluted to $10 \mathrm{~mL}$ with deionized water. Next, the metal content ( $\mathrm{Zn}, \mathrm{Pb}, \mathrm{Ni}, \mathrm{Cu}$ and $\mathrm{Cd}$ ) was measured using flame absorption spectrometry (Unicam 939 Solar). The quality of the analytical procedure was checked using a reference material (Certified Reference Material CTA-OTL-1 Oriental Tobacco Leaves) with the same quantities of samples. The mean recovery percentages of the reference material presented in milligrams of metal-per kilogram dry weight of sample was as followed $115 \%$ of cadmium, $104 \%$ of copper; $106 \%$ of nickel, $110 \%$ of lead and $99 \%$ of zinc.

Analysis of the biochemical parameters of the plants

Crushed plant parts were homogenized in a $100 \mathrm{mM}$ phosphate buffer ( $\mathrm{pH} 6.8)$ for the analysis of POD activity (1:7 ratio) and in a $50 \mathrm{mM}(\mathrm{K} / \mathrm{Na})$ phosphate buffer prior to CAT activity (1:5 ratio) and centrifuged at $12,000 \times \mathrm{g}$ for $20 \mathrm{~min}$. The supernatants were used to determine the enzyme activity levels. The whole procedure was carried out at $4{ }^{\circ} \mathrm{C}$.

The guaiacol peroxidase activity was measured at $470 \mathrm{~nm}$ according to Fang and Kao (2000) with guaiacol as the substrate. The POD activity was measured in a reaction mixture (3 mL) containing a $50 \mathrm{mM}$ phosphate buffer $(\mathrm{pH} 5.8), 1.6 \mu \mathrm{L}$ $\mathrm{H}_{2} \mathrm{O}_{2}, 1.5 \mu \mathrm{L}$ guaiacol and $0.2 \mathrm{~mL}$ enzyme extract. The activity was calculated using the extinction coefficient $\left(26 \mathrm{mM}^{-1} \mathrm{~cm}^{-1}\right)$ for tetra-guaiacol and was expressed in micromoles tetra-guaiacol per minute per milligram protein.

The catalase activity was determined by following the consumption of $\mathrm{H}_{2} \mathrm{O}_{2}$ (an extinction coefficient of $39.4 \mathrm{mM}^{-1} \mathrm{~cm}^{-1}$ ) at $240 \mathrm{~nm}$ for $30 \mathrm{~s}$ (Aebi 1984) and was expressed in $\mu \mathrm{mol}$ consumed $\mathrm{H}_{2} \mathrm{O}_{2} \mathrm{~min}^{-1} \mathrm{mg}$ protein ${ }^{-1}$. The reaction mixture $(3 \mathrm{~mL})$ contained a $50 \mathrm{mM}$ potassium phosphate buffer ( $\mathrm{pH} 7.0), 15 \mathrm{mM} \mathrm{H}_{2} \mathrm{O}_{2}$ and $0.2 \mathrm{~mL}$ enzyme extract.
To measure the contents of non-protein thiols, the plant material was homogenized in a $5 \mathrm{vol} / \mathrm{g}$ mixture containing 5-sulphosalicylic acid (2 g per $100 \mathrm{~mL})$ and $1 \mathrm{mM}$ EDTA and sodium ascorbate $(0.15 \mathrm{~g}$ per $100 \mathrm{~mL})$. The samples were centrifuged at $20,000 \times g$ for $10 \mathrm{~min}$ at $4{ }^{\circ} \mathrm{C}$. Then a $0.5 \mathrm{~mL}$ liquid supernatant, $0.5 \mathrm{~mL}$ of a $1 \mathrm{M}$ sodium phosphate buffer ( $\mathrm{pH} 8.0)$ and $100 \mu \mathrm{l}$ of $10 \mathrm{mM} \mathrm{5,5'-}$ dithio-bis (2-nitrobenzoic acid) (DTNB) were put into test tubes. The absorbance at $415 \mathrm{~nm}$ was read $1 \mathrm{~min}$ after the addition of DTNB. The number of non-protein $\mathrm{SH}$ groups was established based on a curve prepared using L-cysteine and expressed as nanomoles - SH per gram fresh weight (Mass et al. 1987).

The acid-ninhydrin method was used to determine the proline content. The plant material $(0.5 \mathrm{~g})$ was homogenized in $10 \mathrm{~mL}$ of sulfosalicylic acid $(3 \mathrm{~g}$ per $100 \mathrm{~mL})$ and the homogenate was filtered through Whatman No. 2 filter paper. The reaction mixture containing $2 \mathrm{~mL}$ of homogenate, $2 \mathrm{~mL}$ of acid ninhydrin and $2 \mathrm{~mL}$ of glacial acetic acid was incubated at $100{ }^{\circ} \mathrm{C}$ for $1 \mathrm{~h}$. The reaction mixture was placed on ice and extracted with $4 \mathrm{~mL}$ of toluene. The absorbance was read at $520 \mathrm{~nm}$ using toluene as the blank. The proline content expressed in micromoles proline per gram fresh weight was calculated as described by Bates et al. (1973).

The content of total glutathione (GSHt) were measured according to Anderson (1985) procedure and proteins content according to Bradford (1976) procedure using the appropriate standard curves of oxidized glutathione and bovine standard albumin solutions, respectively.

To detect the glutathione concentration, plant parts $(0.5 \mathrm{~g})$ were homogenized in TCA (trichloroacetic acid, $5 \mathrm{~g}$ per $100 \mathrm{~mL}$ ) and a $0.125 \mathrm{mM}$ phosphate buffer (pH6.3) with $6.3 \mathrm{mM}$ EDTA and were centrifuged at $10,000 \times \mathrm{g}$ for $10 \mathrm{~min}$ at $4{ }^{\circ} \mathrm{C}$. Supernatants were used for GSH determinations using the DTNB-oxidized glutathione reductase recycling procedure according to Anderson (1985). The reaction mixture contained $0.2 \mathrm{~mL}$ of supernatant, $0.6 \mathrm{~mL}$ of $0.3 \mathrm{mM}$

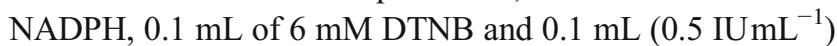
of glutathione reductase (Sigma). The linear changes in the absorbance of the reaction mixtures were measured at $412 \mathrm{~nm}$ and the GSHt was expressed as $\mu \mathrm{mol} \mathrm{GSH} \mathrm{g}^{-1}$ fresh weight.

Statistical assessment

The biochemical parameters data and metal content were analyzed, checked for normality and equality of variance, 
and when necessary the data were log transformed. The data were analyzed by ANOVA and the treatments were treated as the independent variables. Significant statistical differences of all variables were established using the Tukey test (ANOVA; Statistica 8 package). We also calculated the linear correlation coefficient between the metal concentrations in separate soil extractants and in the stems and leaves of $V$. faba, and also, between the metal concentrations and biochemical parameters in the aerial parts of $V$. faba.

\section{Results}

The bioavailability of metals in soil

Soil that was contaminated with metals $(\mathrm{Pb}, \mathrm{Cd}, \mathrm{Cu}, \mathrm{Ni}$, or $\mathrm{Zn)}$ was characterized by higher metal bioavailability in comparison with the control soil. Additionally, there was a clear difference between the concentration of metals in the fraction of soil extracted with $\mathrm{HNO}_{3}$ and the fraction of soil extracted with $\mathrm{CaCl}_{2}$. Among the metals examined, the highest concentrations of $\mathrm{Pb}$ and $\mathrm{Zn}$ were measured in the acid extracted fraction of the soil. A several times lower concentration of the metals examined were measured in the potentially bioavailable fraction $\left(\mathrm{CaCl}_{2}\right.$ extracted). Potentially bioavailable $\mathrm{Cu}, \mathrm{Pb}$ contents made up less than 1-3\% of the metal amounts that were $\mathrm{HNO}_{3}$ extracted (Tables 2 and 3). Compared with $\mathrm{Zn}$ amounts that were acid extracted, $40.2 \%$ of the $\mathrm{Zn}$ was extracted with $\mathrm{CaCl}_{2}$. In addition, $27.5 \%$ of the $\mathrm{Cd}$ was $\mathrm{CaCl}_{2}$ extracted compared with the $\mathrm{Cd}$ amounts that were acid extracted. However, compared to metal doses added to the soil, $\mathrm{Cd}$ was more extractable than $\mathrm{Zn}$ (Tables 1, 3, and 4). The $\mathrm{CaCl}_{2}$ fractions of $\mathrm{Zn}$ and $\mathrm{Cd}$ averaged from 14.8 to $35.5 \%$ of the metal dose (respectively 1,000 and $4 \mathrm{mgkg}^{-1}$ ) amended in the soil.

Heavy metal concentration in plants

The mean values of heavy metal concentrations in $V$. faba leaves and stems were found in a descending order $-\mathrm{Zn}>\mathrm{Ni}>$ $\mathrm{Pb}>\mathrm{Cu}>\mathrm{Cd}$. Generally, the increase in metal concentrations in the leaves and stems of the plants investigated in comparison to the control group was found in metal-contaminated soil (Table 5).We found a strong positive correlation between concentrations of all of the metals examined in separate soil extractants and in particular parts of the plants that were examined. The range of coefficients was $0.53-0.99$ with $p<$ 0.05 . There was no correlation between the $\mathrm{Cd}$ concentration in stems and the $\mathrm{Cd}$ concentration measured in both extractants (Table 6).

The biomass and shoot length

The highest decrease in mean shoot length of $V$. faba plants was found in plants cultivated on soil contaminated with $\mathrm{Zn}$ and $\mathrm{Ni}$ and the decrease was observed also in plants cultivated on soil contaminated with $\mathrm{Cu}$. These metals and $\mathrm{Cd}$ contaminations also caused a reduction in biomass. The highest reduction in plant aerial parts biomass was observed for $\mathrm{Zn}$ - (almost a $95 \%$ decrease in comparison to the control plants) and for Ni-treated plants (a $91 \%$ decrease; Fig. 1).

The biochemical status of the plants

For $\mathrm{Zn}$-treated plant the increase in glutathione was found in leaves, while in the case of $\mathrm{Cu}$ - and Ni-treated plants it was recorded in stems. In the case of $\mathrm{Pb}$ treatment, an elevation was measured in both plant parts. The highest GSHt concentration (79.4 $\mu \mathrm{mol} \mathrm{GSH} \mathrm{g}{ }^{-1}$ fresh weight) was recorded in the leaves of $\mathrm{Zn}$-treated plants, more than 2.6 times than in the control plants (Table 7). The total glutathione pool level was positively correlated with $\mathrm{Zn}$ content in leaves. In addition, a positive correlation was found between $\mathrm{Pb}, \mathrm{Ni}$, and $\mathrm{Cu}$ and glutathione concentration in stems of $V$. faba (Table 8). Generally, a higher GSHt pool was found in stems than in the leaves (cases of $\mathrm{Pb}, \mathrm{Cd}, \mathrm{Cu}$, and $\mathrm{Ni}$ soil treatments). An opposite tendency was recorded for non-protein thiols when their concentrations in leaves and stems were compared. Moreover, their concentration was mostly lower in the leaves of plants that were exposed to metals compared with the controls. In plant stems treated with $\mathrm{Cd}$ and $\mathrm{Zn}$, a decrease in the concentrations of non-protein thiols was
Table 2 The concentrations of selected metals in fractions of the soils $\left(\mathrm{mg} \mathrm{kg}^{-1}\right)$ extracted with $\mathrm{HNO}_{3}$

The different letters denote significant differences between the particular metal concentrations in the fraction extracted with $\mathrm{HNO}_{3}(p<0.05)$

$C$ stands for control in all tables

\begin{tabular}{lclrrr}
\hline $\begin{array}{l}\text { Contamination } \\
\text { variant }\end{array}$ & \multicolumn{5}{l}{ Metal concentration } \\
\cline { 2 - 6 } & $\mathrm{Pb}$ & $\mathrm{Cd}$ & $\mathrm{Cu}$ & \multicolumn{1}{l}{$\mathrm{Ni}$} & \multicolumn{1}{c}{$\mathrm{Zn}$} \\
\hline $\mathrm{Pb}$ & $370.5 \pm 20.5 \mathrm{c}$ & $2.5 \pm 0.02 \mathrm{~b}$ & $2.1 \pm 0.3 \mathrm{a}$ & $0.9 \pm 0.2 \mathrm{a}$ & $10.9 \pm 0.5 \mathrm{a}$ \\
$\mathrm{Cd}$ & $5.1 \pm 1.35 \mathrm{a}$ & $5.1 \pm 0.2 \mathrm{~b}$ & $1.6 \pm 0.1 \mathrm{a}$ & $0.9 \pm 0.1 \mathrm{a}$ & $7.5 \pm 0.6 \mathrm{a}$ \\
$\mathrm{Cu}$ & $18.1 \pm 4.9 \mathrm{~b}$ & $2.4 \pm 0.1 \mathrm{~b}$ & $59.9 \pm 0.8 \mathrm{~b}$ & $0.6 \pm 0.2 \mathrm{a}$ & $10.0 \pm 0.9 \mathrm{a}$ \\
$\mathrm{Ni}$ & $6.7 \pm 0.4 \mathrm{a}$ & $1.4 \pm 0.1 \mathrm{ab}$ & $1.2 \pm 0.1 \mathrm{a}$ & $34.5 \pm 0.3 \mathrm{~b}$ & $13.6 \pm 0.4 \mathrm{a}$ \\
$\mathrm{Zn}$ & $8.5 \pm 0.4 \mathrm{a}$ & $2.1 \pm 0.13 \mathrm{ab}$ & $1.6 \pm 0.2 \mathrm{a}$ & $0.8 \pm 0.1 \mathrm{a}$ & $364.3 \pm 3.5 \mathrm{~b}$ \\
$\mathrm{C}$ & $6.0 \pm 0.2 \mathrm{a}$ & $0.7 \pm 0.2 \mathrm{a}$ & $1.9 \pm 0.1 \mathrm{a}$ & $0.7 \pm 0.2 \mathrm{a}$ & $8.6 \pm 1.0 \mathrm{a}$ \\
\hline
\end{tabular}


Table 3 The concentrations of selected metals in fractions of the soils $\left(\mathrm{mg} \mathrm{kg}^{-1}\right)$ extracted with $\mathrm{CaCl}_{2}$

The different letters denote significant differences between the particular metal concentrations in the fraction extracted with $\mathrm{CaCl}_{2}(p<0.05)$

\begin{tabular}{|c|c|c|c|c|c|}
\hline \multirow{2}{*}{$\begin{array}{l}\text { Contamination } \\
\text { variant }\end{array}$} & \multicolumn{5}{|c|}{ Metal concentration } \\
\hline & $\mathrm{Pb}$ & $\mathrm{Cd}$ & $\mathrm{Cu}$ & $\mathrm{Ni}$ & $\mathrm{Zn}$ \\
\hline $\mathrm{Pb}$ & $1.5 \pm 0.03 \mathrm{~b}$ & $0.3 \pm 0.1 \mathrm{ab}$ & nd & $0.03 \pm 0.01 \mathrm{a}$ & $1.5 \pm 0.04 \mathrm{a}$ \\
\hline $\mathrm{Cd}$ & $1.2 \pm 0.1 \mathrm{~b}$ & $1.4 \pm 0.4 \mathrm{c}$ & nd & $0.04 \pm 0.02 \mathrm{a}$ & $1.3 \pm 0.3 \mathrm{a}$ \\
\hline $\mathrm{Cu}$ & $0.3 \pm 0.1 \mathrm{a}$ & $0.8 \pm 0.03 \mathrm{~b}$ & $1.3 \pm 0.1 \mathrm{a}$ & $0.02 \pm 0.02 \mathrm{a}$ & $1.6 \pm 0.1 \mathrm{a}$ \\
\hline $\mathrm{Ni}$ & $0.4 \pm 0.4 \mathrm{a}$ & $0.3 \pm 0.03 \mathrm{ab}$ & nd & $6.5 \pm 1.6 \mathrm{~b}$ & $1.8 \pm 0.5 \mathrm{a}$ \\
\hline $\mathrm{Zn}$ & $0.3 \pm 0.02 \mathrm{a}$ & $0.5 \pm 0.02 \mathrm{ab}$ & $0.1 \pm 0.01 \mathrm{~b}$ & $0.3 \pm 0.2 \mathrm{a}$ & $146.5 \pm 6.5 \mathrm{~b}$ \\
\hline $\mathrm{C}$ & $0.5 \pm 0.1 \mathrm{a}$ & $0.1 \pm 0.04 \mathrm{a}$ & nd & $0.2 \pm 0.3 \mathrm{a}$ & $1.4 \pm 0.4 \mathrm{a}$ \\
\hline
\end{tabular}

also measured. A higher concentration of non-protein -SH groups in stems of $V$. faba plants treated with $\mathrm{Pb}, \mathrm{Cu}, \mathrm{Ni}$ than in stems of control plants was recorded. It ranged from 89.1 to $205.1 \mathrm{nmol}-\mathrm{SH} \mathrm{g}^{-1}$ fresh weight in this part of the plants (Table 7). Finally, some correlations between nonprotein - $\mathrm{SH}$ groups and metal concentrations in the leaves of examined plants were found, namely a negative relationship in cases of $\mathrm{Pb}$ or $\mathrm{Cd}$, and a positive one in the case of Ni concentration (Table 8).

We detected an increase of proline concentration in the leaves of $V$. faba plants in most cases of metal treatment, as well as in the stems of plants grown on $\mathrm{Zn}$ and $\mathrm{Ni}$ contaminated soil. The concentration of this amino acid was higher in the leaves than in the stems of all plants that were exposed to metals, whereas the control plants had comparable amounts of this amino acid in both organs (Table 7). The proline content positively correlated with $\mathrm{Zn}, \mathrm{Ni}$, and $\mathrm{Cu}$ concentrations in the upper parts (leaves and stems of plants) (Table 8).

The activities of the enzymes CAT and POD were much higher in the stems than in the leaves of the plants examined. General, POD activity was higher in metal stressed plants than in the control. The activity of POD ranged from 93.5 to $182.4 \mu \mathrm{mol}$ tetra-guaiacol $\mathrm{min}^{-1} \mathrm{mg}$ protein ${ }^{-1}$ in leaves and 97.6-236.3 $\mu \mathrm{mol}$ tetra-guaiacol $\mathrm{min}^{-1} \mathrm{mg}$ protein ${ }^{-1}$ in stems. CAT activity was higher in cases of Ni treatment (in both aerial parts of plants) and $\mathrm{Cu}$ or $\mathrm{Zn}$ treatments (but only in the stems of plants) in comparison to the control (Table 9). Positive correlations were found between CAT activity and $\mathrm{Ni}$ concentration in the leaves and $\mathrm{Zn}, \mathrm{Cu}$ concentrations in the stems of plants. A negative correlation

Table 4 Heavy metal bioavailability comparison in contaminated soil samples $\left(\mathrm{CaCl}_{2}\right.$ extraction)

\begin{tabular}{llllll}
\hline Metal & $\mathrm{Pb}$ & $\mathrm{Cd}$ & $\mathrm{Cu}$ & $\mathrm{Ni}$ & $\mathrm{Zn}$ \\
\hline $\begin{array}{c}\text { Mean concentration in } \\
\text { contaminated soil (mg.kg }\end{array}$ & 1.52 & 1.42 & 1.32 & 6.59 & 148.42 \\
$\begin{array}{c}\text { Availability in \% (applied } \\
\text { metal dose }=100 \%)\end{array}$ & 0.29 & 35.46 & 1.55 & 5.99 & 14.84 \\
& & & & &
\end{tabular}

The heavy metal concentrations in soil extracts were calculated on the basis of soil dry weight was found between the Cd concentration and CAT activity in leaves. In addition, POD activity positively correlated with $\mathrm{Zn}$ content measured in both parts of the plants and with Ni content in stems (Table 8).

\section{Discussion}

Whether treatment with metals increased their bioavailability in soil was evaluated using two metal extractions with $\mathrm{CaCl}_{2}$ and $\mathrm{HNO}_{3}$. The most available among the metals examined were $\mathrm{Cd}$ and $\mathrm{Zn}$ (Tables 3 and 4).

However, the significant differences in the bioavailability among the examined metals depending on $\mathrm{CaCl}_{2}$ and $\mathrm{HNO}_{3}$ extraction should be mentioned. Banjoko and McGrath (1991) found that $\mathrm{CaCl}_{2}$ extractable metal content is much more suitable than total metal content in predicting the bioavailability of heavy metals. Evaluations of the pool of soluble - potentially bioavailable trace elements in soil-are mainly based on different extractions done with various solutions, among which are acids or neutral salts such as $\mathrm{CaCl}_{2}, \mathrm{NaNO}_{3}, \mathrm{NH}_{4} \mathrm{OAc}$ (Kabata-Pendias 2004; Feng et al. 2005). Menzies et al. (2007) found that salts such as $0.01 \mathrm{M} \mathrm{CaCl}_{2}$ and $0.1 \mathrm{M}$ $\mathrm{NaNO}_{3}$ provided the most useful indication of metal phytobioavailability across a range of metals. Pongrac et al. (2009) showed that ammonium acetate $\left(\mathrm{NH}_{4} \mathrm{OAc}\right)$ extraction increased Cd bioavailability (11.3-37.2 \%). Cd extractability was similar to our results obtained after $\mathrm{CaCl}_{2}$ extraction.

Jiang et al. (2010) found that $\mathrm{NH}_{4} \mathrm{OAc}$-extractable $\mathrm{Zn}$ and $\mathrm{Cd}$ concentrations were significantly reduced in multiple metal-contaminated soils planted with the $\mathrm{Zn}$ and $\mathrm{Cd}$ hyperaccumulator Sedum plumbizincicola in comparison with unplanted soils.

Plants, as important components of the ecological system, transfer metals from abiotic to biotic environments. The metal fraction in the soil that interacts with a biological target determines its bioavailability (Chojnacka et al. 2005; Mishra et al. 2009a). In our experiments, some differences in metal concentration series order in the soil extracts and the upper parts of $V$. faba plants were found. The metal concentrations in the soil fraction extracted with $\mathrm{HNO}_{3}$ 
Table 5 The concentrations of heavy metals ( $\mathrm{mg} \mathrm{kg}^{-1}$ d.w.) in the leaves and stems of $V$. faba plants grown in soil contaminated with heavy metals

${ }^{a}$ Denotes significant differences between the metal concentration in leaves and stems in one variant of contamination

${ }^{\mathrm{b}}$ Denotes significant differences between the metal concentration in plants grown in the contaminated soil and the control $(p<0.05)$

\begin{tabular}{|c|c|c|c|c|c|}
\hline \multirow{2}{*}{$\begin{array}{l}\text { Contamination } \\
\text { variant }\end{array}$} & \multicolumn{5}{|c|}{ Metal concentration } \\
\hline & $\mathrm{Pb}$ & $\mathrm{Cd}$ & $\mathrm{Cu}$ & $\mathrm{Ni}$ & $\mathrm{Zn}$ \\
\hline \multicolumn{6}{|l|}{ Leaves } \\
\hline $\mathrm{Pb}$ & $20.41 \pm 2.78^{\mathrm{a}, \mathrm{b}}$ & $0.38 \pm 0.15$ & $0.62 \pm 0.16^{\mathrm{a}, \mathrm{b}}$ & $3.43 \pm 0.32^{\mathrm{a}}$ & $51.86 \pm 6.51^{\mathrm{b}}$ \\
\hline $\mathrm{Cd}$ & $4.34 \pm 0.34^{\mathrm{a}, \mathrm{b}}$ & $1.58 \pm 0.06^{\mathrm{a}, \mathrm{b}}$ & $2.17 \pm 0.32^{\mathrm{a}}$ & $3.88 \pm 0.80^{\mathrm{a}}$ & $50.42 \pm 3.92^{\mathrm{b}}$ \\
\hline $\mathrm{Cu}$ & $0.85 \pm 0.11^{\mathrm{a}, \mathrm{b}}$ & $0.24 \pm 0.09$ & $3.53 \pm 0.35^{\mathrm{b}}$ & $5.43 \pm 0.17^{\mathrm{a}, \mathrm{b}}$ & $22.30 \pm 0.63^{\mathrm{a}, \mathrm{b}}$ \\
\hline $\mathrm{Ni}$ & $0.27 \pm 0.04^{\mathrm{a}}$ & $0.10 \pm 0.04^{\mathrm{b}}$ & $2.78 \pm 0.28^{\mathrm{b}}$ & $85.42 \pm 8.69^{\mathrm{a}, \mathrm{b}}$ & $58.50 \pm 1.57^{\mathrm{a}, \mathrm{b}}$ \\
\hline $\mathrm{Zn}$ & $0.69 \pm 0.14^{\mathrm{a}, \mathrm{b}}$ & $0.14 \pm 0.02^{\mathrm{a}}$ & $3.30 \pm 0.25^{\mathrm{b}}$ & $8.60 \pm 1.33^{\mathrm{b}}$ & $1748.50 \pm 24.15^{\mathrm{a}, \mathrm{b}}$ \\
\hline $\mathrm{C}$ & $0.19 \pm 0.06^{\mathrm{a}}$ & $0.09 \pm 0.05$ & $1.85 \pm 0.03$ & $3.87 \pm 0.42^{\mathrm{a}}$ & $34.74 \pm 2.38^{\mathrm{a}}$ \\
\hline \multicolumn{6}{|l|}{ Stems } \\
\hline $\mathrm{Pb}$ & $16.35 \pm 0.72^{\mathrm{a}, \mathrm{b}}$ & $0.21 \pm 0.10$ & $1.57 \pm 0.21^{\mathrm{a}}$ & $9.83 \pm 0.59^{\mathrm{a}, \mathrm{b}}$ & $58.41 \pm 1.77^{\mathrm{b}}$ \\
\hline $\mathrm{Cd}$ & $1.29 \pm 0.06^{\mathrm{a}}$ & $0.62 \pm 0.07^{\mathrm{a}, \mathrm{b}}$ & $1.48 \pm 0.22^{\mathrm{a}}$ & $7.21 \pm 0.24^{\mathrm{a}}$ & $48.47 \pm 6.10^{\mathrm{b}}$ \\
\hline $\mathrm{Cu}$ & $0.58 \pm 0.08^{\mathrm{a}, \mathrm{b}}$ & $0.35 \pm 0.04^{\mathrm{b}}$ & $3.83 \pm 0.22^{\mathrm{b}}$ & $6.76 \pm 0.41^{\mathrm{a}}$ & $27.60 \pm 1.72^{\mathrm{a}, \mathrm{b}}$ \\
\hline $\mathrm{Ni}$ & $0.09 \pm 0.05^{\mathrm{a}, \mathrm{b}}$ & $0.13 \pm 0.02$ & $2.82 \pm 0.20^{\mathrm{b}}$ & $50.07 \pm 3.92^{\mathrm{a}, \mathrm{b}}$ & $19.83 \pm 1.64^{\mathrm{a}, \mathrm{b}}$ \\
\hline $\mathrm{Zn}$ & $2.12 \pm 0.13^{\mathrm{a}, \mathrm{b}}$ & $0.40 \pm 0.05^{\mathrm{a}, \mathrm{b}}$ & $3.38 \pm 0.21^{\mathrm{b}}$ & $10.65 \pm 0.44^{\mathrm{b}}$ & $1211.25 \pm 131.04^{\mathrm{a}, \mathrm{b}}$ \\
\hline $\mathrm{C}$ & $1.23 \pm 0.17^{\mathrm{a}}$ & $0.15 \pm 0.03$ & $1.87 \pm 0.08$ & $6.82 \pm 0.42^{\mathrm{a}}$ & $64.90 \pm 2.50^{\mathrm{a}}$ \\
\hline
\end{tabular}

decreased as follows: $\mathrm{Pb}=\mathrm{Zn}>\mathrm{Cu}>\mathrm{Ni}>\mathrm{Cd}$ and for the $\mathrm{CaCl}_{2}$ extracts decreased with order $\mathrm{Zn}>\mathrm{Ni}>\mathrm{Pb}=\mathrm{Cu}=\mathrm{Cd}$. In general, the metal concentrations series order in stems and leaves was similar as in $\mathrm{CaCl}_{2}$ extractants $-\mathrm{Zn}>\mathrm{Ni}>\mathrm{Pb}>\mathrm{Cu}>\mathrm{Cd}$. Similar trends were also observed by Celik et al. (2005) in the case of Robinia pseudoacacia. The metal concentrations measured in R. pseudoacacia was in the order of $\mathrm{Fe}>$ $\mathrm{Mn}>\mathrm{Zn}>\mathrm{Pb}>\mathrm{Cu}>\mathrm{Cd}$. The increase of $\mathrm{Zn}, \mathrm{Ni}, \mathrm{Pb}$ and $\mathrm{Cu}$ in the upperparts of plants cultivated in our experiments was concomitant with an increase in metal concentrations in the fractions of soil extracted with $\mathrm{CaCl}_{2}$ and $\mathrm{HNO}_{3}$.

In this study, we found a higher concentration of metals (except $\mathrm{Cu}$ ) in the leaves than in the stems of plants on metal contaminated soil. Similar results were obtained by Probst et al. (2009) during a cultivation experiment using $V$. faba, in which metal concentrations in plant roots, leaves and shoots were measured. Metal concentration - and generally bioaccumulation-was in the following order: roots $>$ leaves $>$ stems, except of $\mathrm{Pb}$ and $\mathrm{Cd}$. In our study, the highest amounts of $\mathrm{Zn}$ and $\mathrm{Ni}$ among examined metals were accumulated in the leaves and stems of $V$. faba plants and this caused the most toxic effects on plant growth (Table 5).
Generally, toxic concentrations of $\mathrm{Cd}$ and $\mathrm{Pb}$ for plants are defined in ranges of 5-30 and $30-300 \mathrm{mgkg}^{-1} \mathrm{~d}$.w., respectively. Toxicity limits for $\mathrm{Zn}$ are in the range of 300$400 \mathrm{mgkg}^{-1}$ d.w., depending on the plant species and the growth stage. $\mathrm{Ni}$ is readily taken up from soils by plants and its phytotoxic concentration range is generally 40-246 mg $\mathrm{kg}^{-1}$ d.w., whereas toxicity limits for $\mathrm{Cu}$ were established in the range of 20-100 $\mathrm{mg} \mathrm{kg}^{-1}$ d.w. (Alloway and Ayres 1999; Kabata-Pendias 2001). In our investigation, the measured concentrations of $\mathrm{Pb}\left(20.4 ; 16.3 \mathrm{mg} \mathrm{kg}^{-1}\right.$ in leaves and stems respectively), $\mathrm{Cd}\left(1.6 ; 0.6 \mathrm{mg} \mathrm{kg}^{-1}\right)$ and $\mathrm{Cu}(3.5 ; 3.8 \mathrm{mg}$ $\left.\mathrm{kg}^{-1}\right)$ in the aboveground parts of $V$. faba were below the toxic threshold. The $\mathrm{Zn}$ concentration in plants grown in soil amended with this metal (1211.3-1748.5 $\left.\mathrm{mgkg}^{-1}\right)$ was much higher than the established toxic threshold. The Ni concentration detected in leaves and stems $(85.4 ; 50.1 \mathrm{mg}$ $\mathrm{kg}^{-1}$ ) was within the toxic range for this metal. The toxicity caused by heavy metals is a concern because it inhibits plant growth thus leading to a lower yield; it also causes a deterioration in crop quality (Guo et al. 2004). In our experiment, we found that plant shoot lengths decreased (except for $\mathrm{Cd}$ - and $\mathrm{Pb}$-treated plants) and that there was a reduction

Table 6 The correlation coefficients between the concentrations of particular metals in separate soil extractants $\left(\right.$ with $\mathrm{HNO}_{3}$ or $\left.\mathrm{CaCl}_{2}\right)$ and in the leaves and stems of $V$. faba plants $(p<0.05)$

\begin{tabular}{|c|c|c|c|c|c|c|c|c|c|c|}
\hline & \multicolumn{2}{|l|}{$\mathrm{Pb}$} & \multicolumn{2}{|l|}{$\mathrm{Cd}$} & \multicolumn{2}{|l|}{$\mathrm{Cu}$} & \multicolumn{2}{|l|}{$\mathrm{Ni}$} & \multicolumn{2}{|l|}{$\mathrm{Zn}$} \\
\hline & $\mathrm{HNO}_{3}$ & $\mathrm{CaCl}_{2}$ & $\mathrm{HNO}_{3}$ & $\mathrm{CaCl}_{2}$ & $\mathrm{HNO}_{3}$ & $\mathrm{CaCl}_{2}$ & $\mathrm{HNO}_{3}$ & $\mathrm{CaCl}_{2}$ & $\mathrm{HNO}_{3}$ & $\mathrm{CaCl}_{2}$ \\
\hline Leaves & 0.97 & 0.81 & 0.92 & 0.84 & 0.53 & 0.59 & 0.99 & 0.97 & 0.90 & 0.90 \\
\hline Stems & 0.99 & 0.72 & NS & NS & 0.60 & 0.66 & 0.99 & 0.97 & 0.98 & 0.90 \\
\hline
\end{tabular}

NS not significant 
Fig. 1 The mean shoot length and weight of an aerial part per plant (in \% of control) of $V$. faba plants cultivated in the control and in soil contaminated with individual heavy metal. Control features constituted $100 \%$

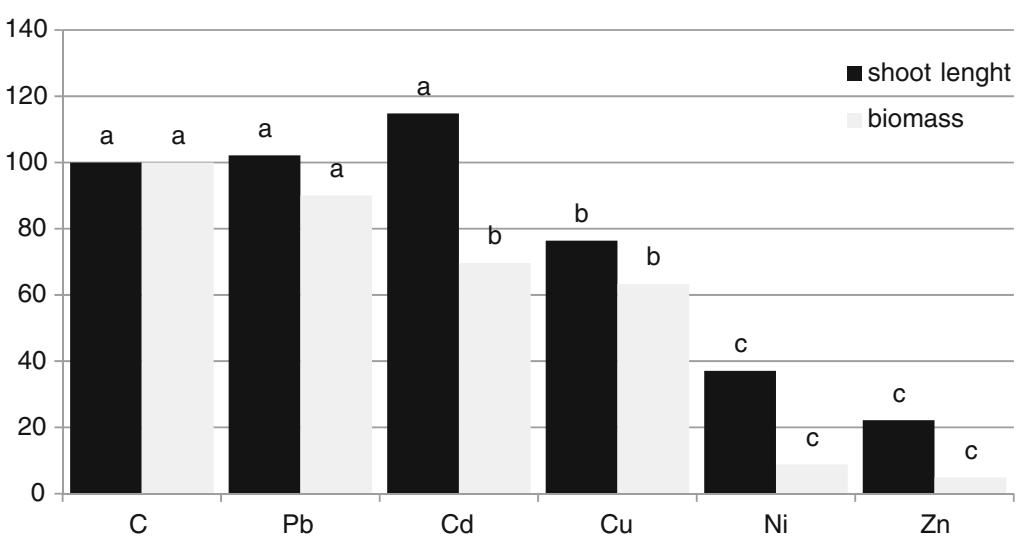

In our experiment, a variation in the antioxidant level, which was dependent on metal treatment, was noticed. In addition to enzymatic antioxidants, non-enzymatic antioxidants are important in heavy metals plants defense (Gill and Tuteja 2010).

An increase in GSH in the leaves of plants cultivated in soil contaminated with $\mathrm{Pb}$ and $\mathrm{Zn}$ was found. $\mathrm{Zn}$ content in $V$. faba leaves as well as glutathione content in this part of the plant positively correlated with the available $\mathrm{Zn}$ in soil (correlation coefficient 0.92). Similar results were obtained by Wang et al. (2010). Nocito et al. (2006) found that Cd and Zn affected the GSHt content of roots in different ways. An increase of the glutathione pool was noticed in the leaves of Philadelphus coronarius grown on a polluted site (Kafel et al. 2010). Treatment of $R$. pseudoacacia with $\mathrm{Pb}$ in investigations by Wińska-Krysiak and Bernat (2008) showed that $\mathrm{Pb}$ at a dose of $45 \mathrm{mg} \mathrm{Pb}^{2+} \mathrm{mg}^{-1}$ in a hydroponic culture did not affect the GSHt level in roots, while in leaves the metal at this concentration led to an increase that was twice as high in comparison with the control plants. This can be attributed to the high demand of plants for GSH due to the synthesis of phytochelatins in response to a high accumulation of $\mathrm{Pb}$ in these organs.

Glutathione creates complexes with heavy metals and an induction of glutathione as well as cysteine synthesis has been documented in plants as a response to heavy metals stress (Arya et al. 2008). The changes in GSHt level are toxic metals (Liu at al. 2004; Gill and Tuteja 2010).

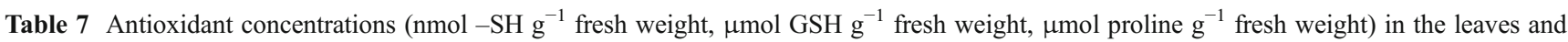
stems of $V$. faba plants grown on soil contaminated with heavy metals

\begin{tabular}{|c|c|c|c|c|c|c|}
\hline & \multicolumn{2}{|l|}{ Glutathione } & \multicolumn{2}{|c|}{ Non-protein -SH groups } & \multicolumn{2}{|l|}{ Proline } \\
\hline & Leaves & Stems & Leaves & Stems & Leaves & Stems \\
\hline $\mathrm{Pb}$ & $38.1 \pm 0.7^{\mathrm{a}, \mathrm{b}}$ & $42.3 \pm 2.1^{\mathrm{a}, \mathrm{b}}$ & $270.4 \pm 16.7^{\mathrm{a}, \mathrm{b}}$ & $145.9 \pm 6.8^{\mathrm{a}, \mathrm{b}}$ & $0.8 \pm 0.06^{\mathrm{a}, \mathrm{b}}$ & $0.4 \pm 0.02^{\mathrm{a}}$ \\
\hline $\mathrm{Cd}$ & $16.4 \pm 0.4^{\mathrm{a}}$ & $29.6 \pm 0.3^{\mathrm{a}}$ & $247.2 \pm 2.0^{\mathrm{a}, \mathrm{b}}$ & $89.1 \pm 3.6^{\mathrm{a}, \mathrm{b}}$ & $0.8 \pm 0.03^{\mathrm{a}, \mathrm{b}}$ & $0.4 \pm 0.02^{\mathrm{a}}$ \\
\hline $\mathrm{Cu}$ & $16.7 \pm 1.2^{\mathrm{a}, \mathrm{b}}$ & $40.1 \pm 0.9^{\mathrm{a}, \mathrm{b}}$ & $290.8 \pm 5.5^{\mathrm{a}}$ & $205.1 \pm 12.4^{\mathrm{a}, \mathrm{b}}$ & $0.6 \pm 0.02^{\mathrm{a}}$ & $0.2 \pm 0.02^{\mathrm{a}}$ \\
\hline $\mathrm{Ni}$ & $30.3 \pm 0.9^{\mathrm{a}}$ & $42.1 \pm 0.5^{\mathrm{a}, \mathrm{b}}$ & $311.4 \pm 14.2^{\mathrm{a}}$ & $147.7 \pm 4.4^{\mathrm{a}, \mathrm{b}}$ & $2.7 \pm 0.04^{\mathrm{a}, \mathrm{b}}$ & $2.2 \pm 0.02^{\mathrm{a}, \mathrm{t}}$ \\
\hline $\mathrm{Zn}$ & $79.4 \pm 7.8^{\mathrm{a}, \mathrm{b}}$ & $36.4 \pm 0.9^{\mathrm{a}}$ & $278.1 \pm 11.1^{\mathrm{a}, \mathrm{b}}$ & $93.0 \pm 4.0^{\mathrm{a}, \mathrm{b}}$ & $3.2 \pm 0.01^{\mathrm{a}, \mathrm{b}}$ & $2.2 \pm 0.02^{\mathrm{a}, \mathrm{l}}$ \\
\hline $\mathrm{C}$ & $29.5 \pm 1.5$ & $31.9 \pm 3.1$ & $309.8 \pm 13.5^{\mathrm{a}}$ & $123.3 \pm 8.5^{\mathrm{a}}$ & $0.5 \pm 0.02$ & $0.3 \pm 0.01$ \\
\hline
\end{tabular}

${ }^{a}$ Denotes significant differences between the antioxidant concentrations in the leaves and stems data in one variant of contamination

${ }^{\mathrm{b}}$ Denotes significant differences between the heavy metal concentrations in plants grown in the contaminated soil and the control $(p<0.05)$ 
Table 8 The correlation coefficients between metal concentration and antioxidant measurements in the leaves and stems of $V$. faba plants $(p<0.05)$

\begin{tabular}{|c|c|c|c|c|c|c|c|c|c|c|}
\hline & \multicolumn{2}{|l|}{$\mathrm{Pb}$} & \multicolumn{2}{|l|}{$\mathrm{Cd}$} & \multicolumn{2}{|l|}{$\mathrm{Cu}$} & \multicolumn{2}{|l|}{$\mathrm{Ni}$} & \multicolumn{2}{|l|}{$\mathrm{Zn}$} \\
\hline & Leaves & Stems & Leaves & Stems & Leaves & Stems & Leaves & Stems & Leaves & Stems \\
\hline Glutathione concentrations & NS & 0.38 & -0.41 & NS & NS & 0.41 & NS & 0.48 & 0.92 & NS \\
\hline Non-protein thiols & -0.37 & NS & -0.76 & NS & NS & NS & 0.45 & NS & NS & NS \\
\hline Proline concentrations & NS & NS & NS & NS & 0.42 & 0.45 & 0.55 & 0.68 & 0.74 & 0.61 \\
\hline Peroxidase level & NS & NS & NS & NS & NS & NS & NS & 0.47 & 0.81 & 0.59 \\
\hline Catalase level & NS & NS & -0.51 & NS & NS & 0.53 & 0.71 & NS & NS & 0.95 \\
\hline
\end{tabular}

NS not significant

dependent on the metal treatment and the part of plant. The level of glutathione increases significantly under most metal treatment, at least, in one of the examined plant parts (stems or leaves). In this work, this level was positively related with concentration of metals $(\mathrm{Pb}, \mathrm{Cu}, \mathrm{Ni})$ in stems (Tables 7 and 8) most of the time. It is interesting that in the case of $\mathrm{Zn}$ (which exhibits significant effects on plant growth, which was mentioned above), we found a positive correlation between GSHt and the $\mathrm{Zn}$ concentration in the leaves of $V$. faba. In contrast to our findings for two varieties of Abelmoschus esculentus exposed to mine spoil, an increase of GSH was measured mainly in the leaves rather than in other organs, where the level of this tripeptide declined (Arya et al. 2008). Arya and Roy (2011) found that in Mntreated $V$. faba, the GSHt content was higher in the roots than in the stems. Moreover, the increase of total glutathione content was positively related to an increase in the $\mathrm{Mn}$ concentration in the roots and stems along with the duration of experiment. The total glutathione content initially increased up to $40 \mu \mathrm{M} \mathrm{Mn}$ and then declined with an increase in Mn concentrations. El-Beltagi and Mohamed (2010) found that an increase in $\mathrm{Pb}$ accumulation in Raphanus sativus leaves and roots was correlated with increasing metal concentration exposure to plants, although a decreasing trend in glutathione level was observed.
Glutathione might play a key role among non-protein thiols in a defense against a $\mathrm{Zn}$ surplus in the case of $V$. faba plants. In addition to a higher GSHt pool, a decrease in non-protein - $\mathrm{SH}$ groups was registered in $\mathrm{Zn}$-treated plants in our study (Table 7).

A tolerance to metals may be due to changes in the content of non-protein thiols, which includes glutathione thiol-rich peptides (known as phytochelatins) or other - $\mathrm{SH}$ rich compounds. Pro-oxidant compounds, such as $\mathrm{H}_{2} \mathrm{O}_{2}$, can selectively oxidize thiols. Molecules containing sulfur, which exist in a wide variety in cells, may fulfill different functions and may be independently regulated (Mishra et al. $2009 b$ ). In our study, the content of non-protein thiols decreased in the leaves and stems in Cd- and Zn-treated $V$. faba plants. This was similar to the study of De la Rosa et al. (2005). The production of thiols decreased in the leaves of Salsola kali at the highest tested concentration of $\mathrm{Cd}$.

Moreover, in the case of $\mathrm{Cu}$ and $\mathrm{Ni}$ exposure in our study, apart from GSH, the role of non-protein thiols might be important in a defense response against an elevation in metals. We found a significant elevation of GSH and nonprotein thiols in $V$. faba stems.

Most of the general responses of $V$. faba plants to different metals appear to be connected with the participation of peroxidase and proline. In our investigation, an increase of

Table 9 Antioxidant enzyme activity (respectively, $\mu$ mol tetra-guaiacol $\min ^{-1} \mathrm{mg}_{\text {grotein }}^{-1}, \mu \mathrm{mol}$ consumed $\mathrm{H}_{2} \mathrm{O}_{2} \mathrm{~min}^{-1} \mathrm{mg} \mathrm{protein}^{-1}$ ) in the leaves and stems of $V$. faba plants grown on soil contaminated with heavy metals

\begin{tabular}{lllll}
\hline & \multicolumn{2}{l}{ Guaiacol peroxidase } & & \multicolumn{2}{l}{ Catalase } \\
\cline { 2 - 3 } & Leaves & Stems & Leaves & Stems \\
\hline $\mathrm{Pb}$ & $117.09 \pm 3.83^{\mathrm{a}, \mathrm{b}}$ & $185.12 \pm 17.4^{\mathrm{a}, \mathrm{b}}$ & $71.6 \pm 5.5^{\mathrm{a}}$ & $234.0 \pm 32.2^{\mathrm{a}}$ \\
$\mathrm{Cd}$ & $108.29 \pm 2.37^{\mathrm{a}, \mathrm{b}}$ & $171.47 \pm 14.02^{\mathrm{a}, \mathrm{b}}$ & $36.8 \pm 8.7^{\mathrm{a}, \mathrm{b}}$ & $207.1 \pm 41.0^{\mathrm{a}}$ \\
$\mathrm{Cu}$ & $83.52 \pm 1.59^{\mathrm{a}, \mathrm{b}}$ & $126.17 \pm 6.8^{\mathrm{a}, \mathrm{b}}$ & $35.0 \pm 2.5^{\mathrm{a}, \mathrm{b}}$ & $265.7 \pm 39.7^{\mathrm{a}, \mathrm{b}}$ \\
$\mathrm{Ni}$ & $128.57 \pm 17.82^{\mathrm{a}, \mathrm{b}}$ & $217.12 \pm 3.35^{\mathrm{a}, \mathrm{b}}$ & $99.7 \pm 17.5^{\mathrm{a}, \mathrm{b}}$ & $73.0 \pm 27.1^{\mathrm{a}, \mathrm{b}}$ \\
$\mathrm{Zn}$ & $182.39 \pm 4.45^{\mathrm{a}, \mathrm{b}}$ & $236.34 \pm 6.05^{\mathrm{a}, \mathrm{b}}$ & $75.1 \pm 9.4^{\mathrm{a}}$ & $708.1 \pm 118.6^{\mathrm{a}, \mathrm{b}}$ \\
$\mathrm{C}$ & $93.50 \pm 3.21$ & $97.63 \pm 2.95$ & $58.4 \pm 11.1^{\mathrm{a}}$ & $187.5 \pm 70.9^{\mathrm{a}}$ \\
\hline
\end{tabular}

${ }^{a}$ Denotes significant differences between the enzyme activity in the data for leaves and stems in one variant of contamination

${ }^{\mathrm{b}}$ Denotes significant differences between the enzyme level in plants grown in the contaminated soil and the control $(p<0.05)$ 
peroxidase activity in stems and leaves (except for $\mathrm{Cu}$-treated plants) and proline concentration in leaves was established among plants treated with different metals. A similar effect, an elevated proline level, was measured in leaves of cabbage plants treated with $\mathrm{Co}, \mathrm{Ni}$, and Cd (Teklić et al. 2008). Verma and Dubey (2003) observed an increase of peroxidase in the stems and roots of rice cultivars after $\mathrm{Pb}$ treatment; however, the increase of the proline content was specific to plants from different experimental groups. In our experiment, the highest proline content was found in both aboveground parts (leaves and stems) of $V$. faba plants grown in soil contaminated with $\mathrm{Zn}$ or Ni. Proline accumulation is regarded as an indicator of environmental stress. Upregulation of proline under heavy metal stress conditions is often found in plants ranging from algae to angiosperms. A higher level of this amino acid increases the stress tolerance of plants through such mechanisms as osmoregulation, protection of enzymes against denaturation or stabilization of protein synthesis (Schat et al. 1997; Zengin and Munzuroglu 2005; Sharma and Dietz 2006; Xu et al. 2009). Sharma and Dietz (2006) listed several examples of flowering plants (Cajanus cajan, Vigna mung, Helianthus annus, Lemna minor, Triticum aestivum, Lactuca sativa, Silene vulgaris, Oryza sativa) that respond to heavy metals through an increase in proline level. In a field study, Kafel et al. (2010) registered an increase in proline level in the aboveground parts of $P$. coronarius in conditions of heavy metal traffic contamination. Zengin and Munzuroglu (2005) detected a significant increase of proline content along with ascorbic acid and $\alpha$-tocopherol in bean leaves grown in a solution spiked with various concentrations of $\mathrm{Pb}, \mathrm{Cu}, \mathrm{Cd}$ and $\mathrm{Hg}$.

POD enhancement was registered in the leaves of plants (except $\mathrm{Cu}$ ) as well as in the stems (all metal treatments). The experiments of Hassan et al. (2008) and Shamsi et al. (2008) also showed POD enhancement in conditions of metal contamination in soybean plants exposed to $\mathrm{Cd}$ and in rice plants exposed to $\mathrm{Cd}$ in a hydroponic experiment. Elevated superoxide dismutase (SOD) and POD activities in the leaves and roots of barley along with an accumulation of $\mathrm{Al}, \mathrm{Cd}$ and $\mathrm{Cu}$ were estimated by Guo et al. (2007).

Guaiacol peroxidase can be induced by heavy metals and is more efficient than CAT in eliminating $\mathrm{H}_{2} \mathrm{O}_{2}$ (Wang et al. 2010). It must be mentioned that the enhancement of antioxidant enzymes may be due to the upregulation of their genes expression. Antioxidant enzymes like SOD, CAT and ascorbate peroxidase upregulation are implicated in combating the oxidative stress caused by biotic and abiotic stress (including heavy metals) (Gill and Tuteja 2010). But the upregulation response may depend on the metal concentration as in the example of Lepidium sativum, where the upregulation of the enzymes took place in the presence of 100 and $200 \mathrm{mgkg}^{-1} \mathrm{~Pb}^{2+}$ representing a lower and moderate stress, while in the presence of higher concentrations, elevated expression was detected only at $400 \mathrm{mg} \mathrm{kg}^{-1}$ for CAT and ascorbate peroxidase.

Peroxidases, which are stress enzymes in plants, were used as a potential biomarker for sublethal toxicity in spruce seedlings (Radotić et al. 2000). Wang et al. (2010) found that for $\mathrm{Pb}$-treated $V$. faba plants, POD enhancement and ascorbate peroxidase activity might be employed as an intrinsic and major defense tool responsible for $\mathrm{H}_{2} \mathrm{O}_{2}$ degradation under higher concentrations of $\mathrm{Pb}$, in contrast to CAT, whose activity was reduced.

The elevation of CAT activity in Ni- or Zn-treated plants was noted in our study. Kafel et al. (2010) showed a similar phenomenon - an increase of CAT activity in the aboveground parts of $P$. coronarius grown in conditions of environmental pollution. In a pot experiment, Lin et al. (2007) showed that in $V$. faba exposed to $\mathrm{Cd}$ at $5 \mu \mathrm{gmL}^{-1}$, the activities of POD, CAT, and SOD were significantly decreased, thus leading to an accumulation of reactive oxygen species.

POD activity enhancement in the leaves and stems of $V$. $f a b a$ as well as proline accumulation in plants treated with $\mathrm{Pb}, \mathrm{Zn}$ and $\mathrm{Ni}$ seem to be promising in investigations of a plant's defense tools against the oxidative stress caused by heavy metals. A higher level of antioxidant defense was recorded in $V$. faba leaves and stems treated with $\mathrm{Zn}$ and $\mathrm{Ni}$ in comparison to plants treated with other metals. These results are related to the bioavailability of these metals and their higher accumulation within the plants.

\section{Conclusions}

The general markers of different metal treatments in our experiment were POD activity and proline content. These parameters seem to be universal antioxidant defense factors against heavy metal exposure. The levels of $\mathrm{Zn}, \mathrm{Ni}, \mathrm{Pb}, \mathrm{Cd}$, and $\mathrm{Cu}$, especially in the leaves of $V . f a b a$, reflected a contamination of the soil with these metals. $\mathrm{Zn}$ and $\mathrm{Ni}$, in the doses investigated, are toxic to $V$. faba and inhibited plant growth (biomass and reduction in shoot lengths). Application of $\mathrm{Zn}$ and Ni led to a significant increase in these metals concentration detected in plants, which probably forced them to invest more energy into anti-oxidative defense. We found several examples of high correlations between antioxidant parameters and concentrations of metals in the upper parts of plants, higher POD and CAT activity as well as proline content, and in the case of $\mathrm{Zn}$ a higher GSHt content. The bioavailability of single metals and plant heavy metal response in particular cultivation investigations are recommended for the safe production of crops after contamination. 
Acknowledgments This work was financially supported by the Polish State Committee for Scientific Research, Project No. N305 007 31/0334.

Open Access This article is distributed under the terms of the Creative Commons Attribution License which permits any use, distribution, and reproduction in any medium, provided the original author(s) and the source are credited.

\section{References}

Aebi H (1984) Catalase in vitro. Methods Enzymol 105:121-126

Alloway BJ, Ayres DC (1999) Heavy metals. In: Chemical basis of environment air pollution. PWN, Warszawa, pp 218-246 (in Polish)

Anderson ME (1985) Determination of glutathione and glutathione disulfide in biological samples. Methods Enzymol 113:548-555

Arya SK, Roy BK (2011) Manganese induced changes in growth, chlorophyll content and antioxidants activity in seedlings of broad bean (Vicia faba L.). J Environ Biol 32:707-711

Arya SK, Khalique S, Roy BK (2008) Glutathione and cysteine biosynthesis in two varieties of Abelmoschus esculentus in response to mine spoil. J Environ Biol 29(1):93-99

Banjoko V, McGrath S (1991) Studies of the distribution and bioavailability of soil zinc fractions. J Sci Food Agric 57(3):325-334

Bates L, Waldren R, Teare D (1973) Rapid determination of free proline for water-stress studies. Plant Soil 39:205-207

Bouwman L, Bloem J, Römkens P, Boon G, Vangronsveld J (2001) Beneficial effects of the growth of metal tolerant grass on biological and chemical parameters in copper - and zinc contaminated sandy soils. Minerva Biotechnol 13:19-26

Bradford M (1976) A rapid and sensitive method for the quantization of microgram quantities of protein utilizing the principle of protein dye binding. Anal Biochem 44:276-287

Celik A, Kartal AA, Akdoğan A, Kaska Y (2005) Determining the heavy metal pollution in Denizli (Turkey) by using Robinio pseudo-acacia L. Environ Int 31:105-112

Chojnacka K, Chojnacki AH, Górecka H, Górecki H (2005) Bioavailability of heavy metals from polluted soils to plants. Sci Total Environ 337:175-182

Cui Y, Wang Q (2006) Physiological responses of maize to elemental sulphur and cadmium stress. Plant Soil Environ 52(11):523-529

De la Rosa G, Martinez-Martinez A, Pelayo H, Peralta-Videa JR, Sanches-Salcido B, Gardea-Toresdey JL (2005) Production of low molecular weights thiols as a response to cadmium uptake by tumbleweed (Salsola kali). Plant Physiol Biochem 43:491498

El-Beltagi H, Mohamed AA (2010) Changes in nonprotein thiols, some antioxidant enzymes activity and ultrastructural alteration in radish plant (Raphanus sativus L) grown under lead toxicity. Not Bot Hort Agrobot Cluj 38(3):76-85

Fang WC, Kao C (2000) Enhanced peroxidase activity in rice leaves in response to excess iron, copper and zinc. Plant Sci 158:71-76

Feng MH, Shan XQ, Zhang SZ, Wen B (2005) Comparison of a rhizosphere-based method with other one-step extraction methods for assessing the bioavailability of soil metals to wheat. Chemosphere 59:939-949

Gill SS, Tuteja N (2010) Reactive oxygen species and antioxidant machinery in abiotic stress tolerance in crop plants. Plant Physiol Biochem 48:909-930

Gratão PL, Polle A, Lea PJ, Azevedo RA (2005) Making the life of heavy metal-stressed plants a little easier. Funct Plant Biol $32: 481-494$
Guo T, Zhang G, Zhou M, Wu F, Chen J (2004) Effect of aluminium and cadmium toxicity on growth and enzyme activities of two barley genotypes with different $\mathrm{Al}$ resistance. Plant Soil 258:241-248

Guo TR, Zhang GP, Zhang YH (2007) Physiological changes in barley plants under combined toxicity of aluminium, copper and cadmium. Colloids and Surfaces B 57:182-188

Hassan JM, Shafi M, Zhang G, Zhu Z, Qaisar M (2008) The growth and some physiological responses of rice to Cd toxicity as affected by nitrogen form. Plant Growth Regul 54:125-132

Jiang J, Wu L, Li N, Luo Y, Liu L, Zhao Q, Zhang L, Christie P (2010) Effects of multiple heavy metal contamination and repeated phytoextraction by Sedum plumbizincicola on soil microbial properties. Eur J Soil Biol 46:18-26

Kabata-Pendias A (2001) Trace elements in soils and plants, 3rd edn. CRC, Boca Raton FL, pp 132, 154, 168, 330

Kabata-Pendias A (2004) Soil-plant transfer of trace elements - an environmental issue. Geoderma 122:143-149

Kafel A, Nadgórska-Socha A, Gospodarek J, Babczyńska A, Skowronek M, Kandziora M, Rozpendek K (2010) The effects of Aphis fabae infestation on the antioxidant response and heavy metal content in field grown Philadelphus coronarius plants. Sci Total Environ 408(5):1111-1119

Kasim W (2005) The correlation between physiological and structural alterations induced by copper and cadmium stress in broad beans (Vicia faba L.) Egypt. J Biol 7:20-32

Kucharski R, Sas-Nowosielska A, Małkowski E, Japenga J, Kuperberg JM, Pogrzeba M, Krzyżak J (2005) The use of indigenous plant species and calcium phosphate for stabilization of highly metal polluted sites in southern Poland. Plant Soil 273:291-305

Lin A, Zhang X, Chen M, Cao Q (2007) Oxidative stress and DNA damages induced by cadmium accumulation. J Environ Sci 19:596-602

Liu J, Xiong ZT, Li TY, Huang H (2004) Bioaccumulation and ecophysiological responses to copper stress in two populations of Rumex dentatus L. from copper contaminated and noncontaminated sites. Environ Exp Bot 52:43-51

Lopareva-Pohu A, Garçon G, Lounès-Hadj Sahraoui A, Pourrut B, Debiane D, Waterlot C, Laruelle F, Bidar G, Douay F, Shirali P (2011) Influence of fly ash aided phytostabilisation of $\mathrm{Pb}, \mathrm{Cd}$ and $\mathrm{Zn}$ highly contaminated soils on Lolium perenne and Trifolium repens metal transfer and physiological stress. Environ Pollut 159(6):1721-1729

Mass F, De Kok L, Peters J, Kuiper PA (1987) Comparative study on the effects of $\mathrm{H}_{2} \mathrm{~S}$ and $\mathrm{SO}_{2}$ fumigation on the growth and accumulation of sulfate and sulfhydryl compounds in Trifolium pratense L., Glycine max Merr., Phaseolus vulgaris L. J Exp Bot 38:1459-1469

Meng Q, Zou J, Jiang W, Liu D (2007) Effect of $\mathrm{Cu}^{2+}$ concentration on growth, antioxidant enzyme activity and malondialdehyde content in garlic (Allium sativum L.). Acta Biol Crac 49(1):95-101

Menzies NW, Donn MJ, Kopittked PM (2007) Evaluation of extractants for estimation of the phytoavailable trace metals in soils. Environ Pollut 145:121-130

Mishra S, Tiwari A, Shukla B, Seth C (2009a) Effects of soil amendments on the bioavailability of heavy metals from zinc mine tailings. Environ Monit Assess 155:467-475

Mishra S, Tripathi RD, Srivastava S, Dwivedi S, Trivedi PK, Dhankher OP, Khare A (2009b) Thiol metabolism play significant role during cadmium detoxification by Ceratophyllum demersum L. Bioresour Technol 100:2155-2161

Nocito F, Lancilli C, Crema B, Fourcroy P, Davidian J-C, Sacchi GA (2006) Heavy metal stress and sulfate uptake in maize roots. Plant Physiol 141:1138-1148

Ostrowska A, Gawliński S, Szczubiałka Z (1991) In: Method of analysis and estimate soil and plants property, Catalogue of the Environmental Protection Institute Warsaw pp 334-336 (in Polish)

Page W, Feller U (2005) Selective transport of zinc, manganese, nickel, cobalt and cadmium in the root system and transfer to the leaves in young wheat plants. Ann Bot 96:425-434 
Pongrac P, Zhao FJ, Razinger J, Zrimec A, Regvar M (2009) Physiological responses to $\mathrm{Cd}$ and $\mathrm{Zn}$ in two $\mathrm{Cd} / \mathrm{Zn}$ hyperaccumulating Thlaspi species. Environ Exp Bot 66:479-486

Probst A, Liu H, Fanjul M, Liao B, Hollande E (2009) Response of Vicia faba L. to metal toxicity on mine tailing substate: geochemical and morphological changes in leaf and root. Environ Exp Bot 66:297-308

Radotić K, Dučić T, Mutavdžić D (2000) Changes in peroxidase activity and isoenzymes in spruce needles after exposure to different concentrations of cadmium. Environ Exp Bot 44:105113

Schat H, Sharma S, Vooijs R (1997) Heavy metal-induced accumulation of free proline in metal tolerant and nontolerant ecotype of Silene vulgaris. Physiol Plant 101:477-482

Shamsi IK, Wie K, Zhang GP, Jilani GH, Hassan MJ (2008) Interactive effects of cadmium and aluminum on growth and antioxidative enzymes in soybean. Biol Plant 52:165-169

Sharma SS, Dietz KJ (2006) The significance of amino acids and amino acid-derived molecules in plant responses and adaptation to heavy metal stress. J Exp Bot 57:711-726

Sun RL, Zhou QZ, Sun FH, Jin CX (2007) Antioxidative defense and proline/phytochelatin accumulationin a newly discovered $\mathrm{Cd}$ hypperacunulator, Solanum nigrum L. Environ Exp Bot 60:468476
Teklić T, Hancock JT, Engler M, Paradicović N, Cesar V, Lepeduš H, Štolfa I, Bešlo D (2008) Antioxidative responses in radish (Raphanus sativus L.) plants stressed by copper and lead in nutrient solution and soil. Acta Biol Crac 50(2):79-86

Verma S, Dubey RS (2003) Lead toxicity induces lipid peroxidation and alters the activities of antioxidant enzymes in growing rice plants. Plant Sci 164:645-655

Wang C, Tian Y, Wang X, Geng J, Jiang J, Yu H, Wang C (2010) Leadcontaminated soil induced oxidative stress, defense response and its indicative biomarkers in roots of Vicia faba seedlings. Ecotoxicology 19:1130-1139

Wei Z, Woonchung J, Chen D (2003) Speciation of heavy metal binding non-protein thiols in Agropyron elongatum by sizeexclusion HPLC-IPC-MS. Microchem J 74:207-213

Wińska-Krysiak M, Bernat JJ (2008) Lead tolerance mechanisms In Robinia pseudoaccacia L.- an attempt to practical approach. Acta Sci Pol Hortorum Cultus 7(3):77-86

Xu J, Yin HX, Li X (2009) Protective effects of proline against cadmium toxicity in micropropagated hyperaccumulator, Solanum nigrum L. Plant Cell Rep 28:325-333

Zengin F, Munzuroglu O (2005) Effect of some heavy metals on content of chlorophyll, proline and some antioxidant chemicals in bean (Phaseolus vulgaris L.) seedlings. Acta Biol Crac 47 (2):157-164 